\title{
The effect of polymer burs on microbiological reduction of carious dentin in deciduous teeth: a systematic review Daniela Silva Barroso de Oliveira ${ }^{1}$, Driely Barreiros ${ }^{1}$, Léa Assed Bezerra da Silva ${ }^{1}$, Raquel Assed Bezerra da Silva ${ }^{1}$, Paulo Nelson-Filho ${ }^{1}$, Erika Cal- vano Küchler ${ }^{1}$
}

${ }^{1}$ Department of Pediatric Dentistry, School of Dentistry of Ribeirão Preto/University of São Paulo, Ribeirão Preto, SP, Brazil

\section{Abstract}

Background. Polymer bur is a new technology that proposes to conserve the dentin that is capable of remineralization. Aim: To conduct a quantitative systematic review to evaluate the effect of polymer burs on the reduction of Streptococcus mutans and Lactobacillus after dentin carious excavation in deciduous teeth. Methods and Material: Two reviewers performed the database to identify the relevant clinical papers. Only papers in English that compared polymer burs with other caries removal techniques with the microbiological aspects as an outcome were included. Papers that evaluated only permanent teeth were excluded. Risk of bias was also assessed. Individual study effect sizes were calculated using Cohen's $d$ formula for the comparisons of microorganism reduction before and after carious excavation. Results: The search resulted in 12 non-duplicated papers. After the revision, only 2 were selected. The quantitative evaluation demonstrated that polymer bur reduces microorganism levels in carious dentin. The larger effect size observed was for Streptococcus mutans in the polymer bur technique ( $r=0.84 ; d=3.12)$, followed by Lactobacillus in the carbide bur technique $(r=0.83 ; d=3.03)$. Conclusion: Polymer burs promoted a significant reduction of microorganism levels, mainly Streptococcus mutans in carious dentin.
Citation: Oliveira, et al. (2016). The effect of polymer burs on microbiological reduction of carious dentin in deciduous teeth: a systematic review. Dentistry 3000. 1:a001 doi:10.5195/d3000.2016.56 Received: July 12, 2016

Accepted: July 23, 2016

Published: October 3, 2016

Copyright: (2016 Oliveira, et al. This is an open access article licensed under a Creative Commons Attribution Work 4.0 United States License.

Email: erikacalvano@gmail.com

\section{Introduction}

Dentinal caries is structurally divided into infected and affected dentin. The superficial layer is the infected dentin. It is irreversible denatured and extensively demineralized. The deeper layer is the affected dentin and is bacteria-free. It is potentially and physiologically remineralizable, with odontoblastic process, sound collagen fibers and apatite crystal bound to the fibers [1-6]. The minimally invasive dentistry concept implies that the infected and irreversibly denatured dentin should be removed selectively to preserve as much as possible sound or potentially remineralizable dentin $[3,7]$. However, a balance between tissue preservation and infected dentin removal should be achieve in order to prevent caries progression [4,8-9].

\section{Conventional methods for} carious dentin removal include manual excavation with hand excavators and burs associated with low or high-handpieces [10]. Both are dependent of the operator's optical and tactile sensitivity and may lead to an unnecessary removal of dental tissues [5,8-12]. Moreover, infected and affected dentin have some differences such as in the hardness, toughness and resilience, which determine the relative efficiency of caries excavation techniques [2].

New techniques have been proposed to conserve dental tissue that is able to remineralize [2$3,6,10-11]$. Polymer burs were developed (Smartbur-SS White Company - Lakewood, NJ, USA) to be used with conventional low-speed handpieces that proposes a selflimiting technology, to provide selective caries removal. These burs are single-use instruments, made with a polymer that presents value of hardness Knoop (KHN) equal to 50. This hardness value is lower than healthy dentin (70-90), but (c) BY

ULIS D-Serle?
New articles in this journal are licensed under a Creative Commons Attribution 4.0 United States License.

This journal is published by the University Library System, University of Pittsburgh as part of its D-Scribe Digital Publishing Program and is cosponored by the University of Pittsburgh Press. 


\begin{tabular}{|c|c|c|c|c|c|c|}
\hline Study & $\begin{array}{l}\text { Number of } \\
\text { participants } \\
\text { and teeth }\end{array}$ & $\begin{array}{l}\text { Age } \\
\text { range }\end{array}$ & $\begin{array}{l}\text { Study } \\
\text { design }\end{array}$ & $\begin{array}{l}\text { Microbiological } \\
\text { evaluation }\end{array}$ & $\begin{array}{l}\text { Microorganisms } \\
\text { analyzed }\end{array}$ & $\begin{array}{l}\text { Authors } \\
\text { conclusions }\end{array}$ \\
\hline $\begin{array}{l}\text { 12. Isik et } \\
\text { al., } 2010\end{array}$ & $\begin{array}{l}24 \text { patients } \\
48 \text { teeth }\end{array}$ & $5-9$ & $\begin{array}{l}\text { Same child } \\
\text { received both } \\
\text { treatments } \\
\text { assigned into } 2 \\
\text { groups: } \\
\text { 1) Round carbide } \\
\text { burs } \\
\text { 2) Polymer burs }\end{array}$ & $\begin{array}{l}\text { Growth in culture } \\
\text { media (CFU) and } \\
\text { biochemical } \\
\text { fermentation test }\end{array}$ & $\begin{array}{l}\text { 1) Streptococcus mutans } \\
\text { 2) Lactobacillus } \\
\text { 3) Aerobic microorganisms } \\
\text { 4) Anaerobic microorganisms }\end{array}$ & $\begin{array}{l}\text { No statistically significant } \\
\text { differences in microorganisms } \\
\text { reduction between round } \\
\text { carbide burs and polymer burs } \\
\text { in all microbiological test used. }\end{array}$ \\
\hline $\begin{array}{c}8 . \\
\text { Zakirulla } \\
\text { et al., } \\
2011\end{array}$ & $\begin{array}{c}36 \text { patients } \\
45 \text { teeth }\end{array}$ & $6-14$ & $\begin{array}{l}\text { Division into } 3 \\
\quad \text { groups: } \\
\text { 1) Round carbide } \\
\text { burs } \\
\text { 2) Polymer burs } \\
\text { 3) Spoon } \\
\text { excavator }\end{array}$ & $\begin{array}{l}\text { Growth in culture } \\
\text { media (CFU) }\end{array}$ & $\begin{array}{l}\text { 1) Streptococcus mutans } \\
\text { 2) Lactobacillus }\end{array}$ & $\begin{array}{l}\text { Polymer burs showed } \\
\text { statistically significant more } \\
\text { reduction for Lactobacillus, but } \\
\text { not for } S \text { mutans when } \\
\text { compared with spoon } \\
\text { excavator. Round carbide burs } \\
\text { showed statistically significant } \\
\text { more reduction for } S \text {. mutants } \\
\text { and Lactobacillus when } \\
\text { compared to polymer burs. }\end{array}$ \\
\hline
\end{tabular}

higher than that the carious or infected dentin (0-30) [3-5,10]. Polymer burs have the potential to selectively remove the carious dentin, since they lose their cutting capacity, becoming blunt, when touching the affected and healthy dentin $[3-5,8-9,12]$.

Although several in vitro $[4-5,9-11,13]$ and in vivo $[6,8,12]$ papers evaluated the effectiveness of polymer burs in selectively remove the infected carious dentin, their effect on the microbiological reduction is still imprecise. Thus, the aim of this study was to evaluate the effect of the polymer burs on the reduction of Streptococcus mutans and Lactobacillus after dentin carious excavation in deciduous teeth, through a quantitative systematic review.

\section{Materials and methods}

\section{Protocol and registration}

To conduct this review, the PRISMA STATEMENT checklist was used [14]. The study was registered in the international prospective register of systematic reviews "PROSPERO"

(www.crd.york.ac.uk/PROSPERO) (registration number CRD42015016678).

\section{Search Strategy}

The search strategy was based on the followingMedical Subject Heading terms (MeSH) or Text Word [tw] in different combination strategy: "polymers"

[MeSH terms] OR "polymer" [tw] AND "burs" [tw] OR "bur" [tw] OR "drill" [tw] AND "dental caries" [MeSH terms] OR "caries removal" [tw] OR "caries excavation" [tw].

Using the following databases, the search of the literature was performed: MEDLINE (1966February 2016), Web of Science (1900- February 2016), Scopus
(1960- February 2016) and The Cochrane Library (1993- February 2016).

Attempts to obtain missing information, additional manual search were performed to find further papers that were not in the electronic databases. Reference lists from identified papers were scanned to identify other potentially relevant papers.

\section{Inclusion and Exclusion Criteria}

The inclusion criteria were as follows:

\section{Papers in English.}

\section{Clinical papers.}

3. Papers that evaluate the effect of the polymer burs on the reduction of microorganisms.

\section{The outcome was to evaluate} microbiological aspects. 
The exclusion criteria included the following:

1. Papers in vitro, ex-vivo, case reports, case series, studies with animal models and reviews.

\section{Papers without comparison of} the polymer bur with other technique.

\section{Papers that evaluated only} permanent teeth.

Unpublished results, thesis, book chapters, abstracts and reviews were not included.

\section{Selection Criteria}

All potentially relevant papers were identified by the title and the abstract. After that, the full text analyses were performed to include the paper in the systematic review.

Two examiners (DSBO and DB) evaluated titles, abstracts and full text. If there was a diverging opinion, disagreement among ex- aminers was reexamined in consensus meetings.

\section{Data extraction}

One author (DSBO) extracted the relevant data from the included papers. From each included study, the description of the sample, the study design, microbiological evaluation and results were summarized in the table 1. Other author (ECK) checked the extracted data. Disagreements between the two researchers were resolved by discussion and consensus.

\section{Assessment of risk of bias}

The quality assessment of the remaining papers was performed to evaluate methodological aspects related to influence bias, to gain insight into the results of the techniques comparisons and to guide the interpretation of qualitative and quantitative findings.
Five criteria were used to analyze all included papers: 1 ) sample size calculation; 2 ) random allocation of the participants; 3 ) participants' eligibility, 4) inclusion and exclusion criteria; 5) standardization of the investigator. Two of the reviewers (PNF and ECK) assessed the included papers for risk of bias and were blinded to each other's assessments. Disagreements were resolved through discussions with a third review (RABS). Domains from the Cochrane Collaboration risk of bias tool were assessed for each study. Data were entered into Review Manager 5.3 (RevMan 5.3) for the graphical representation.

\section{Calculation of the effect size}

Comparisons of microorganism reduction before and after dentin carious excavation were performed for each study and each comparison group. In order to pool data, means and standard deviations were converted into

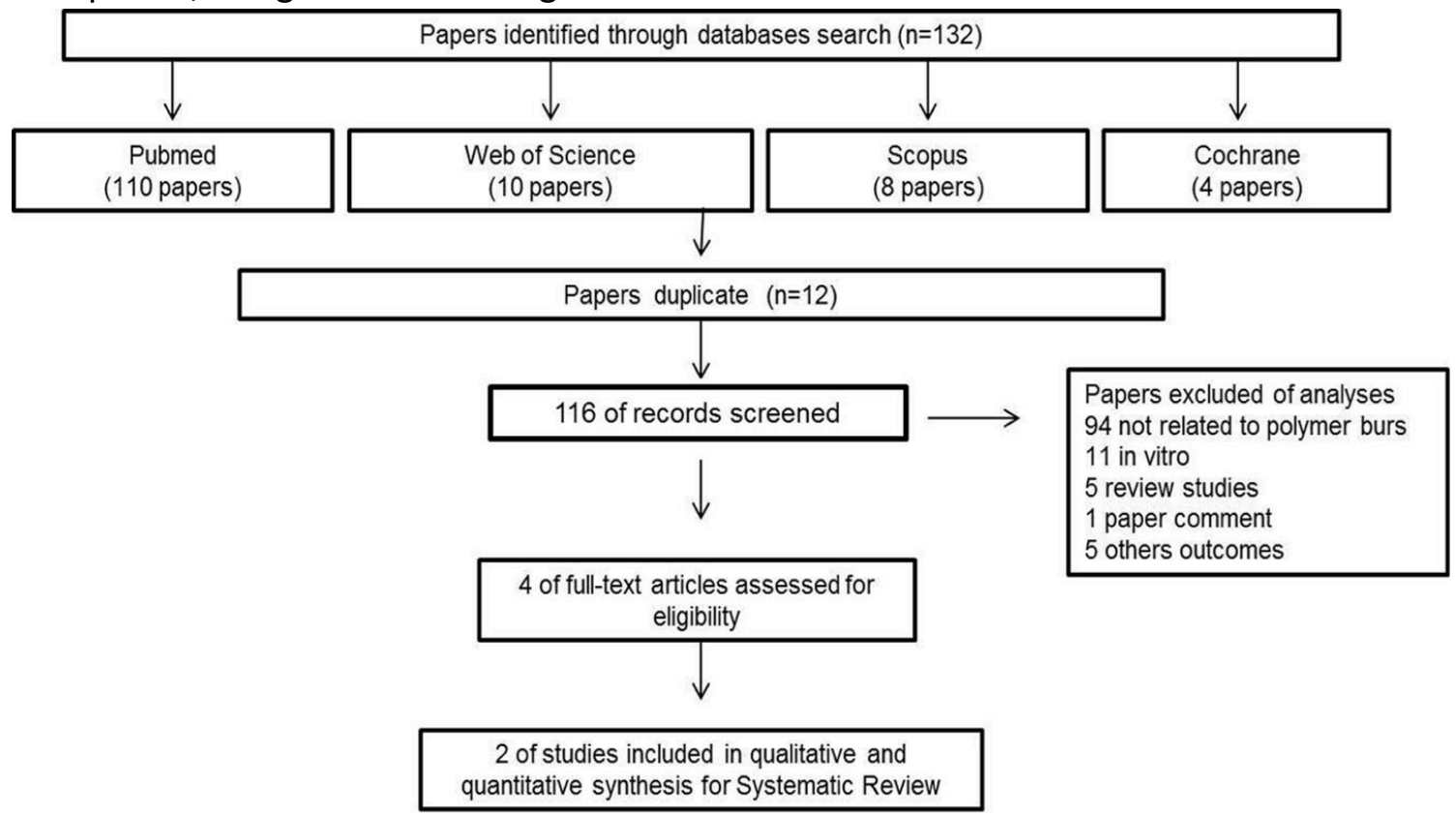

Figure 1. Flow diagram showing the process of selection of the published studies about polymer burs and dental caries. 


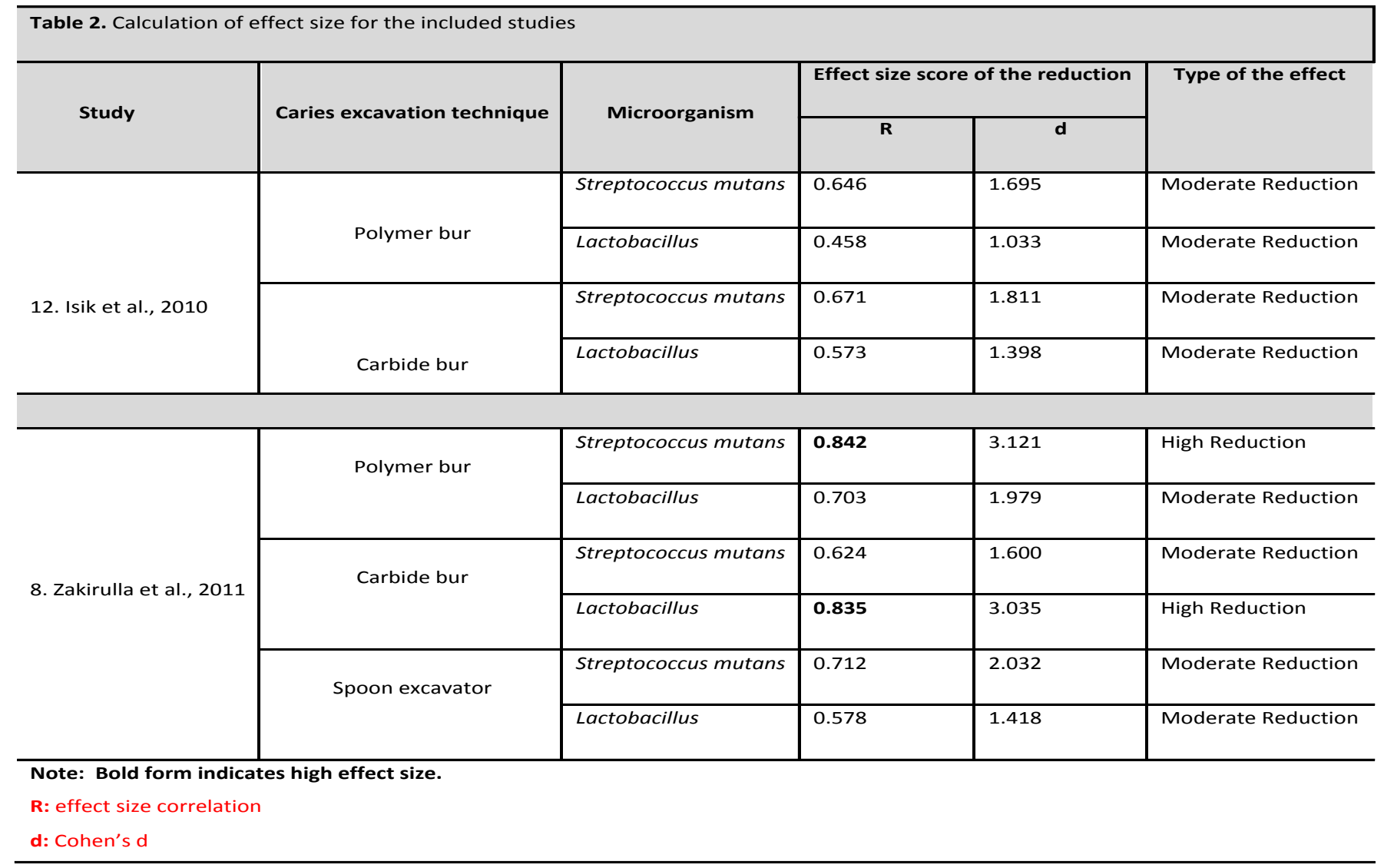

effect size. When the results were presented as median, the mean value and the standard was calculated using the formula proposed by Hozo et al. [15]. Individual study effect sizes for the 2 included papers, that presented the data as a continuous variable, were calculated using Cohen's d formula [16]. Positive values represented a reduction of microorganism level. The effect-size was classified as suggested by Cohen [16], in low effect $(d \leq 0.2)$, medium effect $(0.21 \leq d \geq 0.79)$ and high effect $(d \geq 0.8)$.

\section{Results}

A total of 132 titles and abstracts were screened from the selected databases. There were 110 in PubMed, 10 in Web of Science, 8 in Scopus and 4 in
Cochrane. The duplicates were considered only once, totaling 132 papers.

Initially, the titles and abstracts not connected with the topic were excluded (116 papers). Afterwards, the papers were selected according to the inclusion and exclusion criteria, totaling 4 papers selected for full text analysis. After reading, 2 papers were excluded because they were in vitro papers. Thus, 2 full texts were included and analyzed according to the selection criteria (figure 1).

The summary of the characteristics of the two included papers is described in the table 1. The papers were also carefully read and ranked based on the risk of bias as shown in figure 2 .
The quantitative analysis, that shows the effect size of microorganisms reduction, are presented in the table 2 . All techniques demonstrated a moderate and large reduction of Streptococcus mutans and Lactobacillus levels. The larger effect size observed was for Streptococcus mutans in the polymer bur technique ( $r=0.84 ; d=3.12)$, followed by Lactobacillus in the carbide bur technique ( $r=0.83 ; d=3.03$ ).

\section{Discussion}

The removal of infected carious dentin and the careful maintenance of the dentin that is capable of remineralization has been a focus of the conservative dentistry approaches [3]. The actual criteria for caries removal arise from the concept that 


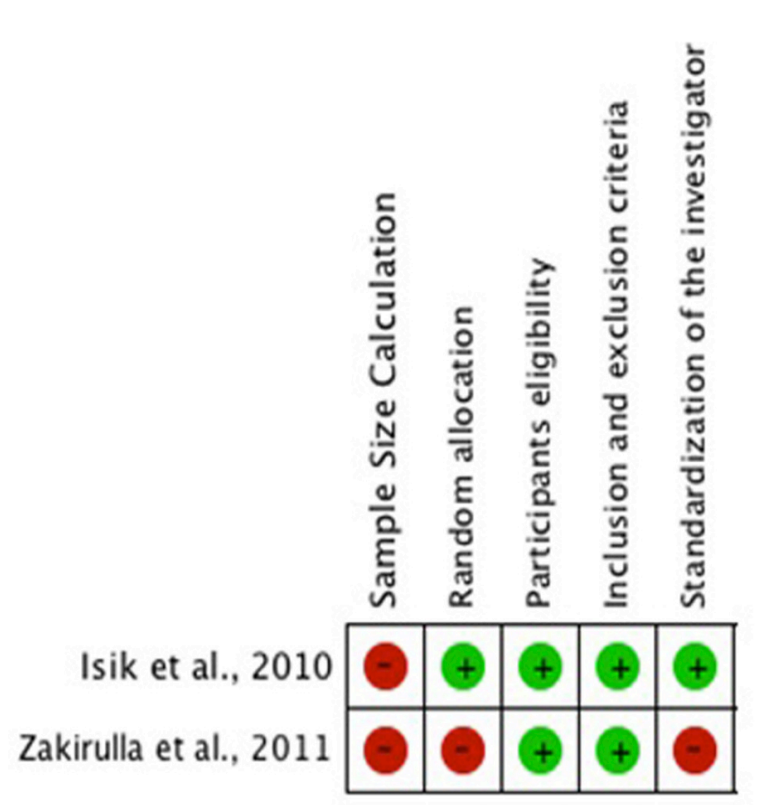

Figure 2. Risk of bias summary. Review authors' judgment about each risk of bias item for the included studies.

"sound" tissue or potentially remineralizable tissue should not be unnecessarily removed $[5,17]$. Nevertheless, the exact endpoint of caries removal cannot be easily clinically defined. This may be explained by the fact that dentists have been trained in relying on the hardness of dentine as felt with a dental probe. Other more subjective characteristics, such as the dentin color and moisture are often neglected [17]. Our quantitative systematic review aimed to evaluate a new technique that proposes to preserve the potentially remineralizable tissue without the dentist's attention to the subjective characteristics.

An important criteria to differentiate infected dentin of affected dentin is the number of viable microorganisms existent in the remaining dentin $[2-4,6]$. Therefore we chose this parameter as an outcome to evaluate the effectiveness of the polymer burs to reduce cariogenic microorganisms. In the present study, the effect size calculation demonstrated that burs, polymer burs and spoon excavator were able to promote a moderate and a large microbiological reduction.

Mutans streptococci are the main etiologic agent of dental caries in humans [18-19], which explains the importance of its reduction after procedures of minimal invasive excavation. Indeed, we observed that polymer bur promoted the largest reduction in Streptococcus mutans levels.

Minimal-invasive dental preparation, such as polymer burs, simplifies and standardizes cariesremoval procedures [17]. In fact, our results demonstrated that polymer burs may offer a viable and efficient means to achieve minimal-invasive dental preparation. Maintain the healthy dental structures as previously described [3-5].

Our results showed that the polymer burs were more ef- fective in Streptococcus mutans removal, while conventional burs provided a further reduction of Lactobacillus. As conventional burs are more invasive than polymer burs and usually extends into the affected dentine $[3,5,13]$, this might lead to a larger reduction of Lactobacilli which are strictly anaerobic, highly sensitive to $\mathrm{pH}$ raising and located in the deeper portions of the carious dentin [20-22].

The included papers have some limitations that directly reflect our review results. None of them attempted to perform a sample size calculation, and only one paper performed a random allocation of used teeth and the standardization of the investigator for the polymer burs use. In addition, it is important to emphasize that a long-term follow up should be perform in order to evaluate a real clinical efficiency regarding the caries lesion recurrence.

Although in all techniques evaluated in the included papers, there was reminiscent number of viable microorganisms in the deeper layers of dentin, we can assume that the subsequent sealing performed by the restoration could solve this issue, as previously demonstrated [23]. Therefore, the maintenance of the cavity sealing through a dentinoenamel junction free from caries and adhesive restorations would interrupt the communication of bacteria present in dentin with the surface biofilm, with a consequent reduction in nutrients and bacterial viability [24]. 


\section{How does a polymer bur actually provide clinical benefits?}

Although this study aimed to answer the question about the efficacy of the polymer burs for microorganism's reduction during carious removal, it raises questions that should be considered by clinical researchers. Microorganisms reduction comparison does not necessary allows the researchers and clinicians to infer which is the most effective method for minimal invasive approach. Furthermore, the use of polymer burs does not eliminate the need of conventional burs, which may be necessary for the enamel removal to access the carious dentin.

The polymer burs proposes for the clinicians a less invasive option for deep decay removal, while leaving healthy dentin intact (Smartbur-SS White CompanyLakewood, NJ, USA). This study demonstrated that conventional methods and the polymer burs reduce levels of Streptococcus mutans and Lactobacillus. However, since the polymer burs are selective for carious dentin remove, it should be an option for clinicians to preserve sound dentin. In addition, it has been proposed that this technique may eliminate the use of local anesthesia ${ }^{3}$. However, the researchers should largely investigate the clinical benefit of this new instrument.

\section{Suggestion for Future Papers}

Based on this systematic review, some questions should be answered in future papers. First, although it is accepted that the dental restoration is effective to deal with the microorganisms left in the remaining dentin, a long term follow up should be performed. Also, since there were no remarkable differences in microorganisms reduction among the minimal invasive techniques, future clinical papers should attempt to evaluate the effectiveness of the polymer bur in a multilevel design study, in which preparation time, peculiarities of this new technique, operator training, assessment of important clinical criteria such as pain, sensitivity to pressure, vibration and temperature changes and cost (single use instrument) of the polymer bur should be included.

Finally, definitive clinical conclusions about the effectiveness of polymer burs were not described in this paper as only one outcome, the microbiological, was evaluated. Other important parameters such as evaluation of hardness, color and humidity are important in assessing the carious dentin removal. Furthermore, papers evaluating the long-term remaining dentin are important to determine if the number of bacteria remaining after carious dentin removal with polymer burs will not be viable for the recurrence of caries. In conclusion, polymer burs promote the reduction of microorganism levels, mainly Streptococcus mutans.

\section{References}

1. Electron microscopic structure of two layers of carious dentin. Ogushi K,
Fusayama T. J Dent Res 1975; Sep-Oct;54(5):101926. PMID: 1058852.

2. New device for selective dentin caries removal. Boston DW. Quintessence International 2003 Oct;34(9): 678-685. PMID: 14982221.

3. Removing carious dentin using a polymer instrument without anesthesia versus a carbide bur with anesthesia. Allen KL, Salgado TL, Janal MN, Thompson VP. J Am Dent Assoc 2005 May; 136(5): 643-651. PMID: 15966653.

4. Efficiency of the polymer bur SmartPrep compared with conventional tungsten carbide bus bur in dentin caries excavation. Dammaschke T, Rondenberg TN, Schäfer E, Ott KHR. Operative Dentistry 2006 Mar-Apr; 31(2):256260. PMID: 16827030

5. Digital image analysis method to assess the performance of conventional and self-limiting concepts in dentin caries removal. Toledano M, Ghinea R, Cardona JC, Cabello I, Yamauti M, Pérz MM, Osorio R. J Den 2013; Aug;41 Suppl 3:e31-8. Epub 2013 Mar 15. PMID: 23507398

6. A comparative clinical study of various methods of caries removal in children. Soni HK, Sharma A, Sood PB. Eur Arch Paediatr 
Dent 2015 Feb; 16(1):1926. PMID: 25391222.

7. Minimal intervention dentistry: rationale of cavity design. Mount GJ. Operative Dentistry 2003 JanFev; 28(1): 92-99. PMID: 12540125.

8. In vivo comparison of reduction in bacterial count after caries excavation with 3 different techniques. Zakirulla M, Uloopi KS, Subba Reddy VV. J Den Child 2011 Jan-Apr; 78(1): 31-35.

PMID: 22041006.

9. Differential resin-dentin bonds created after caries removal with polymer burs. Toledano M, Cabello I, Yamauti M, Osorio R. Microsc Microanal 2012 Jun; 18(3): 497-508. PMID: 22640962

10. Performance of four dentine excavation methods in deciduous teeth. Celiberti $P$, Francescut $P$, Lussi $A$. Caries Res 2006; 40(2): 117-123. PMID: 16508268.

11. Comparison of dentin caries excavation with polymer and conventional tungsten carbide burs. Meller C, Welk A, Zeligowski T, Splieth C. Quintessence Int 2007 Jul-Aug; 38(7): 565-569. PMID: 17694212.

12. A microbiological assessment of polymer and conventional carbide burs in caries removal. Isik EE,
Ölmez A, Akca G, Sultan N. Pediatr Dent 2010 Jul-Aug; 32(4): 316-23. PMID: 20836951.

13. Evaluation of a self-limiting concept in dentinal caries removal. Silva NRFA, CarvaIho RM, Pegoraro LF, Tay FR, Thompson VP. J Dent Res 2006 Mar; 85(3): 282286. PMID: 16498079.

14. Preferred reporting items for systematic reviews and meta-analysis: the PRISMA statement. Moher D, Liberati A, Tetzlaff J, Altman DG, PRISMA Group. Ann Intern Med. 2009 Aug 18;151(4):264-9. PMID: 19622511.

15. Estimating the mean and variance from the median, range, and the size of a sample. Hozo SP, Djulbegovic B, Hozo I. BMC Med Res Mehtodol 2005 Apr 20;5:13. PMID: 15840177.

16. Cohen J (1988) Statistical power analysis for the behavioral sciences. 2nd ed. New Jersey: Lawrence Erlbaum Associates.

17. Caries-removal effectiveness and minimalinvasiveness potential of caries-excavation techniques: A micro-CT investigation. Neves AA, Coutinho E, De Munck J, Meerbeek BV. J Den 2011 Feb; 39(2): 154-162. PMID: 21111770.
18. Role of Streptococcus mutans in human dental decay. Loesche WJ. Microbiological reviews 1986 Dec; 50(4): 353-380. PMID: 3540569 .

19. Recovery of mutans streptococci on MSB, SB-20 and SB-20M agar media. Saravia $M E$, Nelson-Filho $P$, Silva $R A B$, De Rossi A, Faria G, Silva LAB, Emilson CG. Arch Oral Biol 2013 Mar; 58(3): 311-316. PMID: 23149153.

20. Assessing the stage of caries lesion activity on the basis of clinical and microbiological examination. Nyvard B, Fejerskov O. Communty Dent Oral Epidemiol 1997 Feb; 25(1):6975. PMID: 9088694.

21. Evaluation of clinical and microbiological features of deep carious lesions in primary molars. Ayna B, Çelenk S, Atakul F, Sezgin B, Özekinci T. J Dent Child 2003 Jan-Apr; 70(1):15-18. PMID: 12762602.

22. A tissue-dependent hypothesis of dental caries. Simón-Soro Á, Belda-Ferre P, Cabrera-Rubio R, Alcaraz LD, Mira A. Caries Res 2013; 47(6):591-600. PMID: 24080530.

23. Partial caries removal in primary teeth: association of clinical parameters with microbiological status. Lula ECO, Almeida Jr LS, Alves CMC, Monteiro-Neto V, Ribeiro CC. Caries Res 2011; 
entistrப $\exists \square \square \square$

Vol 4, No 1 (2016) DOI 10.5195/d3000.2016.56

45(3):275-280. PMID:

21576960 .

24. How "clean" must a cavity be before restoration?

Kidd EA. Caries Res 2004

May-Jun; 38(3): 305-313.

PMID: 15153704. 